\title{
Examining antecedents and consequences of university brand image
}

\author{
Abdelbaset Alkhawaldeh $^{a^{*}}$, Abdallah Alsaad ${ }^{\mathrm{b}}$, Abdallah Taamneh $^{\mathrm{b}}$ and Hussein Alhawamdeh $^{\mathrm{a}}$
}

${ }^{a}$ Assitant Professor, College of Business Administration; Taibah University, Saudi Arabia

${ }^{b}$ Assitant Professor, The Faculty of Business, Jadara University, Jordan

\begin{tabular}{l}
\hline C H R O N I C L E \\
\hline Article history: \\
Received: September 30, 2019 \\
Received in revised format: No- \\
vember 122019 \\
Accepted: November 12, 2019 \\
Available online: \\
November 12, 2019 \\
\hline Keywords: \\
Brand Familiarity \\
Perceived Service Quality \\
Brand Image \\
Satisfaction
\end{tabular}

This research empirically attempted to assess the effect of brand familiarity and perceived service quality on brand image as well as to explore the position of brand image on student satisfaction in addressing previous efforts' mixed outcomes and bridging the gaps in the private higher education area. The data were collected from students of Jadara university in Jordan. PLS-SEM methods were used to test hypothesized relationships on a sample of 112 students. The findings show that familiarity with the brand and perceived quality of service had an important and beneficial connection with the image of the brand. Also, there was an important and positive connection between brand image and students' satisfaction. The revision has discussed the finding and an implication compared with past studies. These findings have significant implications for private higher education institutions that may be taken into consideration when developing their marketing plan. The finding will help design strategies to increase students' satisfaction and improve brand image. It has also presented some of recommendations for upcoming investigation.

C) 2020 by the authors; licensee Growing Science, Canada

\section{Introduction}

In many nations, the higher education industry plays a major role for the extensive development process (Maekae, 2013). Universities spend millions of dollars each year on investment in teaching (Badran, 2014). In Jordan, this sector has witnessed a boom in the growth of private universities beside the public universities (Ministry of Higher Education \& Scientific Research, 2018). These universities as a whole constitute a valuable part of the economic base of country (Badran, 2014; Hailat, 2016; Wagfi, 2014). In short, a university is no longer just a higher learning institution, it is also a business institution (Azoury et al., 2014, p.1). Of late, competition is rising tremendously in the education industry (Azoury et al., 2014; Duarte et al., 2010; Hemsley-Brown et al., 2016). Private colleges with lower brand images face a competitive market challenge (Chen, 2016, p.23). In this regard, private universities in Jordan are facing many challenges nowadays because of the increasingly intense competition between brands in domestic market (Hailat, 2016). To overcome the challenges of competitive pressures, the institutions in higher education sector are increasingly adopting branding and marketing strategies (Balaji, Roy \& Sadeque, 2016). According to Plungpongpan et al. (2016) in the decision process, prospective students recognize universities that can distinguish themselves by generating powerful brand images (p.572). The universities today spend millions of dollars to burnish their brand image (Azoury et al., 2014). The image is a vital factor when we distinguish between the products and services of companies. In this regard, private academic organizations' have also started to build their brand images and pay more attention to this component in the competitive market to attract more learners (Dejnaka et al., 2016).

* Corresponding author.

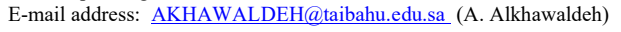


The increase in the competition among the academic organizations has helped them create a unique brand to attract prospective students (Hosseini \& Nahad, 2012; Sung \& Yang, 2008). The positive brand image of a university leads to attract more students, gain external sources of funding and public attitude toward university (Landrum et al., 1999). The studies related to measuring the image of the university are scarce (Hosseini \& Nahad, 2012; Hysi \& Shyle, 2015; Plungpongpan et al., 2016). However, this study will be extended to this context as a fresh zone of marketing management studies especially in developing countries. There is little research in the field of branding management that has mentioned the antecedents of brand image. Brands are the valuable assets for business firms (Alkhawaldeh et al., 2016a). This study aims to expand the prior study that examined the effect of university brand familiarity as the antecedent of university brand image, (Hosseini \& Nahad, 2012) by adding a new construct, which is perceived service quality (Ishaq et al., 2014).

Quality and familiarity with the brand are still the most important criteria for decision (Vermeir \& Verbeke, 2006). The researchers also added the outcome of brand image, i.e. students' satisfaction (Azoury et al., 2014). Universities have to pay attention to students' satisfaction (Chen, 2016). Satisfaction has been seen as a reflection of positive emotional and cognitive states (Quan et al., 2020). Nevertheless, few studies have tried to take into account the impact of these constructs (Azoury et al., 2014; Chen, 2016; Hameed et al., 2014; Hosseini \& Nahad, 2012). In addition to their rarity, these studies have revealed conflicting results. This article suggests to examine the connection between brand familiarity and perceived service quality on brand image, and brand image with students' satisfaction. This study is considered as one of the main issues of the modern marketing management, as this issue has become the center of attention of universities, and it controls the formation of the market. The need of private universities to create their brand on the Jordanian market no longer provokes controversy. The image has become the main factor for academic organizations' and their marketing policies (Dejnaka et al., 2016).

\section{Literature Review}

\subsection{Brand Image}

Brand image is the key element in marketing (Alkhawaldeh et al., 2016b; Chen, 2016). It is a set of beliefs and feelings that is prone merely to a cognitive approach. It allows to distinguish between products and services from others (Dejnaka et al., 2016). It has become the main factor for academic organizations and their marketing policies. According to Azoury et al. (2014) "universities with a powerful unique image will be better to compete effectively in the near future" (p.6). In the universities' context, the primary objective of image management was the need to attract students and distinguish themselves from others (Dejnaka et al., 2016, p.342). The increasing role of the image has resulted in increased competitiveness between universities (Hosseini \& Naha 2012, p. 68). In addition, the significance of the image of academic organizations has a beneficial impact on their location in the rankings (Azoury et al., 2013). Currently, the image of a college is vital in the eyes of overseas candidates in the competitive educational market (Woodall et al., 2014). Consequently, "marketers in the area of higher education service should realize that developing a positive brand image is more important than creating awareness" (Mourad et al., 2011, p. 415). For universities, brand image is critical (Chen, 2016).

Helgesen and Nesset (2007) recorded a favorable impact of college image on the likelihood of students attending new classes at the same university and further education. Similarly, Beerli Palacio et al. (2002) reported that students' experience, understanding, and emotions towards the higher education organization shape the general assessment of university image. Brand image is vital for helping private institution of higher education gain entry to the brand consideration set. Creating the brand image of the private university is essential to the long-term survival of the university (Plungpongpan et al., 2016). Although organizational image has been examined frequently in other sectors, it has been seldom studied in the education arena. There is still lack of literature on the subject of university image, consequently, future studies are recommended to investigate brand image (Ramli et al., 2015).

\subsection{Brand Familiarity}

According to Netemeyer et al. (2004), brand familiarity is seen as the degree to which a customer is familiar with the brand name. It refers to the accumulated consumer experience, including direct and indirect experience, related to the product or service (Yang et al., 2015, p 109). It deals with a customer's past knowledge about the brand (Huang, 2016). Keller (2003), stated that brand familiarity precedes brand evaluation. According to Lee et al. (2012), in the minds of clients, familiar brands are usually extremely significant. In the clutter of competition, it is also a source of competitive advantage. Chen et al. (2015) concluded that brand familiarity affects customers' decision when buying products. Low and Lamb (2000) found that brand familiarity has an impact on brand associations for several products. Brand familiarity is as important as the antecedents of the brand's image (Keller, 1993, 2008; Park, 2009). Increasing familiarity with the brand may generate a positive image to enhance success in brand management (Alba \& Hutchinson, 1987). A prior study found that a brand familiarity was as an important antecedent of brand image (Hosseini \& Nahad, 2012). Nevertheless, another research reported mixed findings (Hameed et al., 2014; Müge \& Korkut, 2010; Park, 2009). Following the above argument, the present research suggests brand familiarity will have an influence on brand image. Thus, 
H1: Brand familiarity has a significant relationship with brand image.

\subsection{Perceived Service Quality}

Perceived service brand quality is a central element of brand equity (Aaker, 1991; Yoo \& Donthu, 2001). Aaker (2012) also postulated the role of perceived quality in building and maintaining brand equity. Perceived quality relates to the judgment about excellence and superiority of a product (Netemeyer et al., 2004; Zeithaml, 1988). It is also defined as the overall judgment about the dimensions of brand values (Aaker, 1991; Aaker \& Jacobson, 1994). Perceived quality as the overall judgment and the generally excellent or superior evaluation by a customer on the quality services (Zeithaml et al., 1988). Perceived quality is consistently an attitude resulting from a comparison of consumer expectations with actual performance (Parasuraman et al., 1985). It is a perception of the consumer regarding the overall superiority of a brand in relation to its intended purpose and relative to alternative brands. Additionally, perceived quality adds value to a purchase decision (Low \& Lamb, 2000). Moreover, perceived quality of a brand encourages clients to engage in citizenship behavior (Raza, 2020).

Perceived quality and reputation create attachment feelings that lead to satisfactory relationships and help to build brand equity (Hemsley-Brown et al., 2016). The quality of the brand is an important aspect for customers when they form a perception about the brand (Müge \& Korkut, 2010). Literature on service marketing in education identifies the university image and perceived quality as important aspects (Helgesen \& Nesset, 2007; Ramli et al., 2015; Vander Schee, 2010). A higher education organization with a powerful brand name conveys a positive image and reputation and is able to deliver high-quality education (Ramli et al., 2015, p22). The outcome showed that the university image and perceived quality of teaching and learning were closely related (Ramli et al., 2015). High-quality of education institutions brands will improve the material and human resources of education institutions. Students are the customers of education institutions, and with high-quality customers, education institutions "universities" can develop maximum profits. Additionally, enhancing the positive quality of education institutions service has become a critical topic in recent years (Chen, 2016).

Quality of lecturers is an essential factor affecting students' satisfaction and providing adequate confidence that a product or service will satisfy given requirements for quality (Ko \& Chung, 2014). However, there are few studies on the service quality on brand image. Ishaq et al. (2014) conducted an empirical research and reported a positive influence on service quality on brand image perceptions of customers. The prior evidence demonstrated that perceived brand quality presents value to customers, leading them to buy the brand, and it is an important point of differentiation (Aaker, 2012). As the perceptions of brand quality improves other brand perceptions, brand quality will increase purchase intention and directly influence organizational performance (Aaker, 1991; Zeithaml, 1988). Thus, this study seeks to discover the effect of service quality on brand image of education institutions. Therefore, this revision attempted to minimize the perceived quality gap in higher education organizations.

\section{H2: Perceived service quality has a significant relationship with brand image.}

\subsection{Student Satisfaction}

Consumers' satisfaction has been a popular subject in marketing. It is the consumer's fulfillment response (Oliver et al., 1997). It is a judgment that characterizes a product or service. According to Chen (2016) students' satisfaction has become vital in academia. Student's satisfaction is a key marketing strategy (Azoury et al., 2014). Higher education institutions have to pay attention to students' satisfaction. Beerli Palacio et al. (2002) stated that brand image of university education institutes and students' satisfaction is the essence needed to establish and enhancement the competitive advantages. Increasingly, students' satisfaction of academic performance is becoming important in understanding their perspective on their learning experiences and it is also becoming an essential indicator of the quality of teaching (Alves \& Raposo, 2007; Ko \& Chung, 2014). Of course, for universities, where competition is growing, students' satisfaction has assumed substantial importance in many countries (Woodall et al., 2014). Loyalty and satisfaction represent reactions to brand-related stimuli (Parasuraman et al.,1988). Ko and Chung (2014) point out that students' satisfaction with their universities has had beneficial impacts on their readiness to recommend the university after graduation and to pursue another degree at the same college or donate to the college.

According to Chen (2016) "When students evaluate satisfaction, they will reflect on their experience on campus" (p.25). Lately, higher education has become a major service, and students have become the clients. Therefore, a study of the factors which drive students' satisfaction would seem to have value (Brown \& Mazzarol, 2009). Obviously, the publication of satisfaction data will noticeably have an impact on good students, and studies that address the satisfaction of students have lately increased (e.g. Chen, 2016; Woodall et al., 2014). Nevertheless, there is little evidence about students' satisfaction as a way of providing universities with a competitive advantage within the developing countries higher education marketplace. Azoury et al. (2014) and Hosseini and Nahad (2012) confirmed that overall images have influenced students' satisfaction at university. Hence, this revision also studied customer satisfaction and tried to find the students' satisfaction. However, it seems that there have been few studies that address the importance of the satisfaction of students and the perception of the brand image (Zhang, 2015). So, this revision tried to minimize this gap in higher education institutions setting. 
H3: Brand image has a significant relationship with student's satisfaction.

Theoretical framework

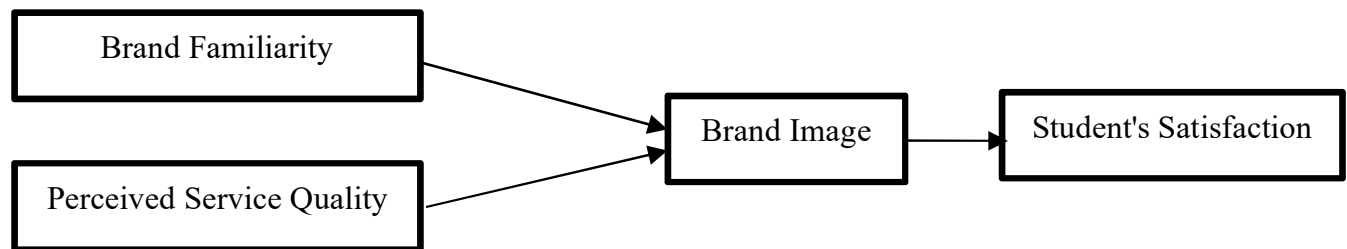

Fig. 1. Proposed model. BF=Brand Familiarity, $P S Q=$ Perceived Service Quality, BI= Brand Image, SS=Student's Satisfaction.

On the theoretical grounds, students who have a strong familiarity with university brand and perceived service quality would probably have a high level of brand image. Also, it is assumed that the higher the university brand image is, the better students' satisfaction will be. In contrast, the earlier research found mixed results (Azoury et al., 2014; Chen, 2016; Hameed et al., 2014; Hosseini \& Nahad, 2012).

\section{Research methodology}

This research used the systematic technique of random sampling. The samples used in the research were 112 Jadara University brand students in Jordan's Irbid Governorate. The questionnaire consisted of sixteen items, the measure was modified and adapted from previous works, including three questions of brand familiarity (Hosseini \& Nahad, 2012), four questions of perceived service quality (Kim \& Lee, 2018), six questions of brand image (Chen, 2016; Hosseini \& Nahad, 2012), and three questions of students' satisfaction (Chen, 2016; Hosseini \& Nahad, 2012). All the items on a 5-point Likert scale were anchored.

\subsection{Data analysis}

\subsubsection{Measurement Model}

Partial Least Square (PLS) analysis technique was used to examine the research model by using Ringle et al. (2015)'s Smart PLS3.0 software. The validity and reliability are two criteria used to test the outer model, according to Hair et al. (2017). Convergent and discriminant validity results are shown respectively in Table 1 and 2 . The composite reliability values and Cronbach's alpha were above the 0.7 limit value, supporting the accuracy of the measures. The AVE values surpassed the 0.5 threshold value, showing a satisfactory convergent validity. Finally, the square root of each AVE was greater than the correlations between the constructs, indicating that the measures have good discriminant validity. Briefly, the validity and reliability of the measurement model were accomplished (Hair et al., 2017; Fornell \& Larcker, 1981).

Table 1

Convergent validity

\begin{tabular}{|c|c|c|c|c|c|}
\hline Construct & Items & Loading & AVE & Alpha & $\mathrm{CR}$ \\
\hline \multirow{3}{*}{ Brand familiarity } & BF 1 & 0.884 & \multirow{3}{*}{0.756} & \multirow{3}{*}{0.839} & \multirow{3}{*}{0.903} \\
\hline & BF 2 & 0.836 & & & \\
\hline & BF 3 & 0.888 & & & \\
\hline \multirow{4}{*}{ Perceived service quality } & PSQ 1 & 0.789 & \multirow{4}{*}{0.664} & \multirow{4}{*}{0.831} & \multirow{4}{*}{0.888} \\
\hline & PSQ 2 & 0.806 & & & \\
\hline & PSQ 3 & 0.792 & & & \\
\hline & PSQ4 & 0.869 & & & \\
\hline \multirow{6}{*}{ Brand image } & BI 1 & 0.729 & \multirow{6}{*}{0.631} & \multirow{6}{*}{0.881} & \multirow{6}{*}{0.911} \\
\hline & BI 2 & 0.799 & & & \\
\hline & BI 3 & 0.86 & & & \\
\hline & BI4 & 0.859 & & & \\
\hline & BI5 & 0.829 & & & \\
\hline & BI6 & 0.671 & & & \\
\hline \multirow{3}{*}{ Student Satisfaction } & SS1 & 0.884 & \multirow[t]{3}{*}{0.689} & \multirow[t]{3}{*}{0.773} & \multirow[t]{3}{*}{0.868} \\
\hline & SS2 & 0.883 & & & \\
\hline & SS3 & 0.71 & & & \\
\hline
\end{tabular}


Table 2

Discriminant Validity-the square root of the AVE

\begin{tabular}{lllll}
\hline & BF & PSQ & BI & SS \\
\hline BF & 0.870 & & & \\
PSQ & 0.630 & 0.815 & & \\
BI & 0.682 & 0.748 & 0.794 & 0.830 \\
SS & 0.495 & 0.653 & 0.656 & \\
\hline
\end{tabular}

\subsubsection{Structural Model}

For testing the outer model, the findings of analysis revealed that coefficient of determination $\left(R^{2}\right)$ for BI $(0.633)$ and SS (0.430) is substantial as stated by Cohen (1988). The findings of the bootstrapping and the path coefficient of hypothesized relationships are shown in Table 3.

Table 3

Path coefficient of Hypotheses

\begin{tabular}{lllllll}
\hline $\mathrm{H}$ & Relationship & Std. Beta & SE & t-Value & Decision & P-value \\
\hline H1 & BF $\rightarrow$ BI & 0.349 & 0.090 & 3.90 & S $^{* * *}$ & 0.000 \\
H2 & PSQ $\rightarrow$ BI & 0.528 & 0.093 & 5.67 & S $^{* * *}$ & 0.000 \\
H3 & BI $\rightarrow$ SS & 0.656 & 0.059 & 11.06 & S $^{* * *}$ & 0.000 \\
\hline
\end{tabular}

Note: $t$-values $>2.58^{* * *}(p<0.01)$, SE $=$ Stander error, $S=$ Supported.

The results revealed that the relationship between brand familiarity and brand image was positive and significant $(\beta=0.349$, $\mathrm{t}=3.90, \mathrm{P}<0.01$ ), providing empirical support for hypothesis $\mathrm{H}_{1}$. Similarly, the relationship between perceived service quality and brand image was positive and significant $(\beta=0.528, \mathrm{t}=5.67, \mathrm{P}<0.01)$, therefore providing support for hypothesis $\mathrm{H}_{2}$. The results also revealed that the relationship between brand image and student's satisfaction was positive and significant $(\beta=$ $0.656, \mathrm{t}=11.06, \mathrm{P}<0.01$ ), thereby providing support for hypothesis $\mathrm{H}_{3}$. Overall, the results revealed that all hypotheses are supported with statistically positive significant.

\section{Discussion}

The outcomes of our revision empirically show the antecedents and consequences of brand image in a higher education setting. The hypothesized relationships were all supported. The results have shown that brand familiarity has a positive relationship on brand image; this result is supported by past revision (e.g. Hosseini \& Nahad, 2012) which found the same outcome. Moreover, the results have shown that perceived service quality has a positive relationship on brand image; this outcome is supported by earlier studies (Ishaq et al., 2014) which found a positive relationship. In short, to explain brand image, brand familiarity and perceived service quality seems to be vital constructs $\left(R^{2}=0.633\right)$. Likewise, brand image had a positive effect on students' satisfaction. This outcome is supported by prior studies (Schlesinger et al., 2017) which found a positive relationship. The study results presented some managerial implications. Marketers of universities' branding need to evaluate the antecedents and consequences of brand image. The above assessment revealed the role of brand familiarity and perceived service quality in generating and retaining brand image. Thus, there is a discussion in the literature about the important connection between brand familiarity and perceived service quality with brand image and brand image on the satisfaction of the students. There are limited studies that have examined this problem in the Arab context, exploring Jordanian students in particular. Hence, institutions of higher education should devote more attention to their brand image. The results highlighted the importance of the relationship elements. Therefore, this empirical value can be utilized for developing marketing plan and planning the long-term relationship with students. Briefly, marketing programs' success is a main factor that determines brand competition. It is expected, through outcomes, to improve the brands in the Arab region in general and in Jordan in particular. In theory, social exchange theory has extended in new context (Emerson, 1976). This revision also expands the concepts of brand image, student satisfaction, brand familiarity and perceived service quality and connections between them. Moreover, the key driver of students' satisfaction is the image of university. Higher education institutions with positive images will be better placed to promote the satisfaction of students (Schlesinger et al., 2017). However, the role of image in the students' satisfaction was overlooked. Accordingly, this study helps in bridging this hole.

\section{Limitations and Recommendations}

A possible limitation of the current study is associated with the context and sample size. Future research should conduct the proposed research framework on a large sample and on public universities. In addition, the factors that were utilized in this research were studies from various literature reviews. This study also included only few antecedents to predict brand image. For this reason, future studies are recommended to test other constructs to expand the model. 


\section{Acknowledgement}

The authors would like to thank the anonymous referees for constructive comments on earlier version of this paper.

\section{References}

Aaker, D. A. (2012). Building strong brands. Simon and Schuster.

Aaker, D. A., (1991). Managing Brand Equity: Capitalizing on the value of a brand name. The Free Press, New York.

Aaker, D. A., \& Jacobson, R. (1994). The financial information content of perceived quality. Journal of Narketing research, 31(2), 191-201.

Alba, J. W., \& Hutchinson, J. W. (1987). Dimensions of consumer expertise. Journal of Consumer research, 13(4), $411-454$.

Alkhawaldeh, A. M., Salleh, S. M., \& Halim, F. B. (2016a), An empirical study in voting behavior and political brand. International Business Management, 10(18), 4365-4372.

Alkhawaldeh, A. M., Salleh, S. M. and Halim, F. B. (2016b), Brand equity and brand loyalty: New perspective. International Review of Management and Marketing 6(4), 722-730.

Alves, H., \& Raposo, M. (2007). Student satisfaction index in Portuguese public higher education. The Service Industries Journal, 27(6), 795-808.

Azoury, N. M., Daou, L. E., \& El Khoury, C. M. (2013). University image and its relationship to student satisfaction: case of the Holy Spirit University of Kaslik, Lebanon. Journal of Executive Education, 12(1), 1-13.

Azoury, N., Daou, L., \& Khoury, C. E. (2014). University image and its relationship to student satisfaction-case of the Middle Eastern private business schools. International Strategic Management Review, 2(1), 1-8.

Badran, A. (October 2014). New trends in Higher Education in Jordan. Education, Economic and Development. In 4th ArabTurkish Congress of Social Sciences, Turkey (pp. 1-28).

Balaji, M. S., Roy, S. K., \& Sadeque, S. (2016). Antecedents and consequences of university brand identification. Journal of Business Research, 69(8), 3023-3032.

Beerli Palacio, A., Díaz Meneses, G., \& Pérez Pérez, P. J. (2002). The configuration of the university image and its relationship with the satisfaction of students. Journal of Educational Administration, 40(5), 486-505.

Brown, R. M., \& Mazzarol, T. W. (2009). The importance of institutional image to student satisfaction and loyalty within higher education. Higher Education, 58(1), 81-95.

Chen, C. T. (2016). The investigation on brand image of university Education and students' word-of-mouth behavior. Higher Education Studies, 6(4), 23-33.

Chen, M. R. A., Chen, S., \& Wu, C. (2015). Motivational orientation and brand familiarity: Positive emotions and skepticism toward online advertising using the English language. Journal of Literature and Art Studies, 5(4), 282-300.

Dejnaka, A., Kulig-Moskwa, K., Łobos, K., Nogieć, J., \& Szewczyk, M. (2016). Students' perception of attributes of independent colleges of business profile in the market of higher education in Poland. Management, 20(2), $340-359$.

Duarte, P. O., Alves, H. B., \& Raposo, M. B. (2010). Understanding university image: a structural equation model approach. International Review on Public and Nonprofit Marketing, 7(1), 21-36.

Emerson, R. M. (1976). Social exchange theory. Annual Review of Sociology, 2(1), 335-362.

Fornell, C., \& Larcker, D. F. (1981). Structural equation models with unobservable variables and measurement error: Algebra and statistics. Journal of Marketing Research, 18(3), 382-388.

Hair, J., Hollingsworth, C. L., Randolph, A. B., \& Chong, A. Y. L. (2017). An updated and expanded assessment of PLSSEM in information systems research. Industrial Management \& Data Systems, 117(3), 442-458.

Hameed, A., Saleem, M. S., Rashid, M., \& Aslam, R. (2014). The impact of brand exten-sion on parent brand image. International Journal of Humanities and Social Science, 4(2), 236-245.

Hailat, K. Q. (2016). The influence of consumer misbehaviour on the perceived brand image of Jordanian Higher Education Institutions (Doctoral dissertation, University of Salford).

Helgesen, Ø., \& Nesset, E. (2007). What accounts for students' loyalty? Some field study evidence. International Journal of Educational Management, 21(2), 126-143.

Hemsley-Brown, J., Melewar, T. C., Nguyen, B., \& Wilson, E. J. (2016). Exploring brand identity, meaning, image, and reputation (BIMIR) in higher education: A special section, Journal of Business Research, http://dx.doi.org/10.1016/j. jbusres.2016.01.016.

Hosseini, M. H., \& Nahad, R. F. (2012). Investigating antecedents and consequences of Open University brand image. International Journal of Academic Research, 4(4), 68-77.

Huang, G. (2016). Moderating role of brand familiarity in cross-media effects: An information processing perspective. Journal of Promotion Management, 22(5), 665-683.

Hysi, V., \& Shyle, I. (2015). The image and perceived quality of universities as important dimensions for building university brand equity-case study involving Albanian students. EJSER European Journal of Social Sciences Education and Research Articles, 3(2), 40-49.

Ishaq, M. I., Hussain, N., Asim, A. I., \& Cheema, L. J. (2014). Brand equity in the Pakistani hotel industry. Revista de Administração de Empresas, 54(3), 284-295.

Keller, K. L. (1993). Conceptualizing, measuring, and managing customer-based brand equity. The Journal of Marketing, 57(1), 1-22. 
Keller, K. L. (2003). Brand synthesis: The multidimensionality of brand knowledge. Journal of consumer Research, 29(4), 595-600.

Keller, K. L. (2008). Strategic brand management, Prentice-Hall, Upper Saddle River, NJ.

Kim, H. K., \& Lee, T. J. (2018). Brand equity of a tourist destination. Sustainability, 10 (431), 1-21.

Ko, W. H., \& Chung, F. M. (2014). Teaching quality, learning satisfaction, and academic performance among hospitality students in Taiwan. World Journal of Education, 4(5), 11-20.

Landrum, R. E., Turrisi, R., \& Harless, C. (1999). University image: the benefits of assessment and modeling. Journal of marketing for Higher Education, 9(1), 53-68.

Lee, M. S. W., Conroy, D., \& Motion, J. (2012). Brand avoidance, genetic modification, and brandlessness. Australasian Marketing Journal (AMJ), 20(4), 297-302.

Low, G. S., \& Lamb Jr, C. W. (2000). The measurement and dimensionality of brand associations. Journal of Product \& Brand Management, 9(6), 350-370.

Maekae, J. (2013). The role of education in national development: Nigerian experience. European Scientific Journal, ESJ, 9(28), 312-320.

Ministry of Higher Education \& Scientific Research. (2018). Retrieved on Feb 07, 2018, from: http://www.mohe.gov.jo/en/pages/PrivateUniversities.aspx

Mourad, M., Ennew, C., \& Kortam, W. (2011). Brand equity in higher education. Marketing Intelligence \& Planning, 29(4), 403-420.

Müge Arslan, F., \& Korkut Altuna, O. (2010). The effect of brand extensions on product brand image. Journal of Product \& Brand Management, 19(3), 170-180.

Netemeyer, R. G., Krishnan, B., Pullig, C., Wang, G., Yagci, M., Dean, D., ... \& Wirth, F. (2004). Developing and validating measures of facets of customer-based brand equity. Journal of Business Research, 57(2), 209-224.

Oliver, R. L., Rust, R. T., \& Varki, S. (1997). Customer delight: foundations, findings, and managerial insight. Journal of retailing, 73(3), 311-336.

Ramli, M. F., \& Salleh, S. M. (2015). Factors contributing to brand loyalty towards Malaysia higher educational institutions. Journal of Education and Vocational Research, 6(3), 22-29.

Raza, M., Salleh, S., Tariq, B., Altayyar, R., \& Shaari, H. (2020). Investigating the effects of customer-based brand equity on turnover intentions with mediating effect of customer citizenship behavior. Management Science Letters, 10(2), $279-286$.

Park, S. H. (2009). The antecedents and consequences of brand image: Based on Keller's customer-based brand equity (Doctoral dissertation, The Ohio State University).

Park, M., \& Lennon, S. (2009). Brand name and promotion in on line shopping contexts. Journal of Fashion Marketing and Management, 13(2), 149-160.

Quan, N., Chi, N., Nhung, D., Ngan, N., \& Phong, L. (2020). The influence of website brand equity, e-brand experience on e-loyalty: The mediating role of e-satisfaction. Management Science Letters, 10(1), 63-76.

Ringle, C. M., Wende, S., \& Becker, J. M. (2015). SmartPLS 3. Boenningstedt: SmartPLS GmbH.

Schlesinger, W., Cervera, A., \& Pérez-Cabañero, C. (2017). Sticking with your university: the importance of satisfaction, trust, image, and shared values. Studies in Higher Education, 42(12), 2178-2194.

Sung, M., \& Yang, S. U. (2008). Toward the model of university image: The influence of brand personality, external prestige, and reputation. Journal of Public Relations Research, 20(4), 357-376.

Parasuraman, A., Zeithaml, V. A., \& Berry, L. L. (1985). A conceptual model of service quality and its implications for future research. Journal of Marketing, 49(4), 41-50.

Parasuraman, A., Zeithaml, V. A., \& Berry, L. L. (1988). Servqual: A multiple-item scale for measuring consumer perc. Journal of Retailing, 64(1), 12.

Plungpongpan, J., Tiangsoongnern, L., \& Speece, M. (2016). University social responsibility and brand image of private universities in Bangkok. International Journal of Educational Management, 30(4), 571-591.

Vander Schee, B. A. (2010). Students as consumers: Programming for brand loyalty. Services Marketing Quarterly, 32(1), 32-43.

Vermeir, I., \& Verbeke, W. (2006). Sustainable food consumption: Exploring the consumer "attitude-behavioral intention" gap. Journal of Agricultural and Environmental ethics, 19(2), 169-194.

Wagfi, A. A. (2014). Corporate Governance: Actual and Aspirations, and Ethical Commitments-A field study-on Private Northern Jordanian Universities (The higher education sector-Jordan). European Journal of Business and Management, 6(10), 71-86.

Woodall, T., Hiller, A., \& Resnick, S. (2014). Making sense of higher education: students as consumers and the value of the university experience. Studies in Higher Education, 39(1), 48-67.

Yang, J., Zhang, M., \& Zou, Z. (2015). The effect of In-Game advertising in SNS on brand equity. Journal of Service Science and Management, $8(01), 107-114$.

Yoo, B., \& Donthu, N. (2001). Developing and validating a multidimensional consumer-based brand equity scale. Journal of Business Research, 52(1), 1-14.

Zeithaml, V. A., Berry, L. L., \& Parasuraman, A. (1988). Communication and control processes in the delivery of service quality. Journal of Marketing, 52(2), 35-48.

Zeithaml, V. A. (1988). Consumer perceptions of price, quality, and value: a means-end model and synthesis of evidence. The Journal of Marketing, 52 (3), 2-22. 
(C) 2020 by the authors; licensee Growing Science, Canada. This is an open access article distributed under the terms and conditions of the Creative Commons Attribution (CCBY) license (http://creativecommons.org/licenses/by/4.0/). 